\title{
Author Correction: Reply to: Fitness effects of CRISPR/Cas9-targeting of long noncoding RNA genes
}

\author{
Ying Liu, Zhiheng Liu D, Zhongzheng Cao and Wensheng Wei (D)
}

Correction to: Nature Biotechnology https://doi.org/10.1038/s41587-020-0431-5, published online 24 February 2020.

In the version of this article initially published online, the name of the organization in the first affiliation was given as Biodynamic Optical Imaging Center. The correct name is Biomedical Pioneering Innovation Center. The error has been corrected in the print, PDF and HTML versions of the article.

Published online: 9 March 2020

https://doi.org/10.1038/s41587-020-0475-6

(๑) The Author(s), under exclusive licence to Springer Nature America, Inc. 2020

\section{Publisher Correction: Engineering bacterial symbionts of nematodes improves their biocontrol potential to counter the western corn rootworm}

\author{
Ricardo A. R. Machado (D), Lisa Thönen (D), Carla C. M. Arce, Vanitha Theepan, Fausto Prada, Daniel Wüthrich, \\ Christelle A. M. Robert (D), Evangelia Vogiatzaki, Yi-Ming Shi (D), Olivier P. Schaeren, Matheus Notter, Rémy Bruggmann, \\ Siegfried Hapfelmeier, Helge B. Bode (D) and Matthias Erb D
}

Correction to: Nature Biotechnology https://doi.org/10.1038/s41587-020-0419-1, published online 17 February 2020.

This article was originally published under the title "Engineering bacterial symbionts of nematodes improves biocontrol potential of the western corn rootworm." The title has been changed to "Engineering bacterial symbionts of nematodes improves their biocontrol potential to counter the western corn rootworm." The error has been corrected in the print, PDF and HTML versions of the article.

Published online: 12 March 2020

https://doi.org/10.1038/s41587-020-0478-3

๑) The Author(s), under exclusive licence to Springer Nature America, Inc. 2020

\section{Publisher Correction: $\gamma \delta$ T cells bring unconventional cancer-targeting to the clinic - again}

Ken Garber

Correction to: Nature Biotechnology https://doi.org/10.1038/s41587-020-0487-2, published online 7 April 2020.

In the version of this article initially published, Jürgen Kuball was quoted as saying that monoclonal antibody and CAR-T cell therapies rely "on the clonal nature of a certain T cell receptor." This should have read "on the clonal nature of a certain receptor." The article also said that $\gamma \delta$ T cells are almost entirely $\mathrm{CD}^{+}$; this characterization has been deleted. Finally, the phrase "only cells with intact receptors retain antitumor activity" was linked to https://cancerimmunolres.aacrjournals.org/content/early/2020/02/04/2326-6066.CIR-19-0513. long; the link has been changed to https://doi.org/10.1182/blood-2012-05-432427. The errors have been corrected in the HTML and PDF versions of the article.

Published online: 21 April 2020

https://doi.org/10.1038/s41587-020-0526-z

(c) The Author(s), under exclusive licence to Springer Nature America, Inc. 2020 